\title{
Ülkemizde Tüketilen Bazı Gıda Ürünleri ile Bisküvilerin Glisemik İndekslerinin İn Vitro Yöntemlerle Belirlenmesi
}

\author{
Jale Çatak ${ }^{1 *}$ \\ 1 İstanbul Sabahattin Zaim Üniversitesi, Beslenme ve Dyetetik Bölümü, İstanbul, Turkey (ODIS: 0000-0002-2718-0967)
}

(İlk Geliş Tarihi 1 Ağustos 2019 ve Kabul Tarihi 26 Ağustos 2019)

(DOI: 10.31590/ejosat.605008)

ATIF/REFERENCE: Çatak, J. (2019). Ülkemizde Tüketilen Bazı Gıda Ürünleri ile Bisküvilerin Glisemik İndekslerinin İn Vitro Yöntemlerle Belirlenmesi. Avrupa Bilim ve Teknoloji Dergisi, (16), 940-947.

$\ddot{\mathbf{O z}}$

Tüm dünyada olduğu gibi ülkemizde de önemli sağlık sorunlarından olan obezite ve diyabetin önlenmesi ve tedavisine yönelik, etkin ve sürdürülebilir çözüm yolları araştırılmaktadır. Diyet kalitesinin esasını teşkil eden glisemik indeks (GI) değerleri, diyabet ve sağlıklı beslenme açısından kritik öneme sahiptir. Düşük Gİ değerine sahip gıdaların Tip 2 diyabet riskini düşürdüğü, yapılan klinik çalışmalarla kanıtlanmıştır ve kalp-damar hastalıkları, obezite ve birçok kronik hastalı̆ı̆ın tedavisinde glisemik kontrolün önemi vurgulanmıştır. Gİ, farklı gıdaların bireylerde oluşturduğu glisemik etkiye (gıda tüketimi sonrası kan şekerinin artışı) göre gıda maddelerinin sınıflandırılması olarak tanımlanmaktadır. Gİ referans aralıkları; $\leq 55$ düşük, 56-69 orta ve $\geq 70$ yüksek Gí olarak kabul edilmektedir. Glisemik indeks (GI), gıdaların bir referans gıda ile karşılaştırılarak, postprandiyal kan glukozuna verdikleri cevaba dayalı bir yöntemdir. Bu çalışmada, ülkemizde sıklıkla tüketilen bazı gıda ürünleri ile bisküvilerin Gİ' leri in vitro glisemik indeks metodu ile belirlenmiştir. Çalışmaya, 2 farklı gıda örneklem grubu dahil edilmiştir. Birinci grupta, Gİ üzerine etki ettiği bilinen farklı lif, karbonhidrat ve nişasta kaynaklarından dolayı; kırmızı mercimek, spagetti ve pirinç unundan oluşan 3 ayrı gıda örneği çalışmaya alınmıştır. İkinci grupta ise, Gĩ üzerine etki eden farklı lif kaynaklarının etkisini kıyaslayabilmek amacıyla yüksek lif içerdiği bilinen ve ara öğünlerde atıştırmalık olarak sıklıkla tüketilen; yulaflı bisküvi, şekersiz form bisküvi ve şekerli form bisküviden oluşan 3 farklı bisküvi örneği ile çalışılmıştır. Analiz edilen kırmızı mercimek, spagetti, pirinç unu, yulaflı bisküvi, şekersiz form bisküvi ve şekerli form bisküvi örnekleri İstanbul'daki marketlerden satın alınmıştır. Glisemik indekste referans alınan beyaz ekmeklerin glisemik indeksleri 66,2-66,4 iken; gıda örneklerinin glisemik indeksleri 33,3-51,7 aralı̆̆ında, bisküvi örneklerinin glisemik indeksleri ise 59,169,9 aralığında bulunmuştur. Form şekersiz bisküvi; light, yulaflı ve kepekli olmasına rağmen Gİ değerinin 70' e yakın (orta, yüksek) olduğu görülmüştür. Analizler üç paralel olarak çalışılmıştır ve verilerin istatistiksel analizleri için Tukey (ANOVA) testinden yararlanılmıştır.

\section{Determination of the Glycemic Indexes of Some Food Products and Biscuits by In Vitro Methods which Consumed in Turkey}

\begin{abstract}
The effective and sustainable solutions are being investigated for the prevention and treatment of obesity and diabetes which are important health problems in our country as in all over the world. Glycemic index (GI) values, which are the basis of the dietary quality, are critical for diabetes and healthy nutrition. It has been proven in clinical studies that foods with low GI values reduce the risk of Type
\end{abstract}

\footnotetext{
* Sorumlu Yazar: İstanbul Sabahattin Zaim Üniversitesi, Beslenme ve Dyetetik Bölümü, İstanbul, Turkey (ODIS: 0000-0002-2718-0967), jalecatak@gmail.com
} 
2 diabetes and the importance of glycemic control in the treatment of cardiovascular diseases, obesity and many chronic diseases has been demonstrated in many clinical studies. GI is defined as the classification of foodstuffs according to the glycemic effect of different foods in individuals (increase of blood sugar after food consumption). GI reference ranges are considered; as low $\leq 55$, as moderate 5669 and as high $\geq 70$ GI. Glycemic index (GI) is a method based on the response of food to postprandial blood glucose compared to a reference food. In this study, GI' s of some food products and biscuits which are frequently consumed in our country were determined by in vitro glycemic index method. Two different food sample groups were included in the study. In the first group, due to different sources of fiber, carbohydrate and starch known to act on GI; 3 different food samples consisting of red lentils, spaghetti and rice flour were included in the study. In the second group, 3 different biscuit samples consisting of oat-based biscuits, sugar-free form biscuits and sugary-form biscuits which are known that contain high fiber and frequently consumed as snacks, were studied in order to compare the effect of different fiber sources acting on GI. Samples of red lentils, spaghetti, rice flour, oat-based biscuits, sugar-free form biscuits and sugary-form biscuits were purchased from the markets in Istanbul. While the glycemic indexes of white breads which referenced in the glycemic index determination were 66,2-66,4; the glycemic indexes of food samples were in the range of 33,3-51,7, and the glycemic indexes of biscuit samples were in the range of 59,1-69,9. Although the sugar-free form biscuit is light and consisting of oat and bran, the GI value was found to be close to 70 (medium, high). The analyzes were performed in three parallel and Tukey (ANOVA) test was used for statistical analysis of the data.

Keywords: Glycemic index, GI, Biscuit, Red lentil, Spaghetti, Rice flour, In vitro

\section{Giriş}

Glisemik indeks (Gi), gıdaların bir referans gıda ile (beyaz ekmek) karşılaştırılarak, postprandiyal kan glukozuna verdikleri cevaba dayanan bir yöntemdir (Foster-Powell ve ark., 2002). 50 g sindirilebilir karbonhidrat içeren test gıdanın tüketilip emilmesini takiben 2 saat içinde oluşturduğu kan glukoz artış alanının, aynı miktarda karbonhidrat içeren referans gıdanın oluşturduğu glukoz artış alanına kıyaslanması ile belirlenmektedir (FAO/WHO, 1998). Buna bağlı olarak karbonhidrattan zengin besinler, düşük Gİ’ li besinler ve yüksek Gİ' li besinler olarak gruplandırılmaktadır. Gİ referans aralıkları; $\leq 55$ düşük, 56-69 orta ve $\geq 70$ yüksek Gİ olarak kabul edilmektedir (Jamurtas ve ark., 2013). Yüksek Gİ' li diyetler; kilo artış1, insülin eksikliği, bozulmuş kan glukozu kontrolü ve artan obezite seviyeleri ile ilişkilendirilmiştir (Brennan, 2005). Son yıllarda ideal diyetler, düşük Gİ li ve düşük karbonhidrat içeren diyetler olarak tanımlanmaktadır. Yapılan araştırmalarda bunun nedeni, düşük Gİ içeren diyetlerin açlık hissi ve enerji alımını düşürdüğü, uzun dönemde ise obezite ve kronik hastalıkları azaltması olarak bildirilmektedir (Bell ve Sears, 2003).

Glisemik indeksin etki mekanizmasının metabolik etkileri glukozun ince bağırsaktan emilme oranı ile ilişkilidir. Bu yüzden, Gì düzeylerini etkileyen en önemli faktör gıdanın içerdiği karbonhidratların yapısıdır. Basit karbonhidratlar, kompleks karbonhidratlara göre bağırsaktan daha hızlı emildiğinden insülin ve tokluk kan şeker düzeylerinde büyük ve hızlı artışlar meydana getirmektedir. Düşük GI' li besinler ince bağırsaktan daha yavaş emilir, bu nedenle sırasıyla postprandiyal kan glukozunda ve insülin seviyesinde daha yavaş yükselme ile sonuçlanmaktadır (Jenkins ve ark., 2002; Wong ve ark., 2010). Karbonhidratın emilim zamanının uzun olması, serbest yağ asitlerinin baskılanmasını ve aynı zamanda kan glukoz konsantrasyonunun düşük olmasını sağlamaktadır (Wong ve ark., 2010).

Karbonhidratların çoğunluğu monosakkaritleri içeren polisakkaritlerden meydana gelmektedir. Günlük diyette en fazla tüketilen polisakkarit, nişastadır. Nişasta enzimler aracılığıyla yıkılır, emilimi ince bağırsakta gerçekleşir ve karbonhidrat metabolizmasının ilk basamağını oluşturur. Nişasta, amiloz ile amilopektinden oluşur ve gıdada amiloz oranının yükselmesi gıdanın Gİ değerinin düşmesi anlamına gelir. Bunun nedeni amilozun alfa amilaz ile hidrolizinden daha az glukoz salınmasıdır. Pirinç, patates, mısır, yulaf, çavdar, buğday, fasulye, tahıl ve baklagil içerikli gıdalarda fazla miktarda nişasta bulunur (TÜRKOMP, 2013). Avrupa Gıda Güvenliği Otoritesi (EFSA)' nin 1924/2006 numaralı yönetmeliğine göre; gıdalar, içerdikleri toplam nişastanın en az \%14'ü dirençli nişasta olduğunda, daha düşük glisemik yanıt verebilmektedir (EFSA, 2012).

Diyabet (DM), pankreasta beta hücrelerinden salınan insülin hormonunun eksikliği veya fonksiyonunu yitirmesi sonucu karbonhidrat, protein ve yağ metabolizmasında bozukluklara yol açan, kronik bir metabolizma ve endokrin hastalığıdır (Chiu ve ark., 2011). Sağlıklı ve TİP 2 DM' li bireylerde yapılan çalışmalarda, karbonhidratların uzun süre boyunca yavaş yavaş tüketildiğinde emilim hızının azaldığı görülmüştür (Wong ve ark., 2010). Dünya Sağlık Örgütü (DSÖ)' ne göre diyabetli birey nüfusunun tüm dünyada 171 milyon civarında olduğu ve bu sayının 2030 yılında 366 milyona ulaşacağı öngörülmektedir (Wild ve ark., 2004). Bir gıdanın glisemik indeksi, özellikle diyabet veya hipoglisemisi olan kişiler için önemlidir; bu kişiler kan glukozunda çok hızlı bir artış ve çok ani bir düşüşe neden olan gıdalardan uzak durmalıdırlar. Düşük glisemik indeks içeren besinlerin kullanıldığı klinik çalışmalarda, diyet glisemik indeksi \%12 4 azaldığı zaman, kan şekeri kontrolünde iyileşme görülmüştür (Peyser ve ark., 2018).

Karbonhidratlı besinlerin seçiminde besin bileşimindeki bilgiyle beraber Gí değerlerinin kullanılması 1998 yılında Gıda Tarım Örgütü (GTÖ) tarafından uygun bulunmuştur. Yine GTÖ' nün 2007 yılında yenilenen 'İnsan Beslenmesinde Karbonhidratlar' kılavuzunda Gİ, karbonhidrat içeren besinlerin seçiminde en uygun yol gösterici olarak belirlenmiştir. Ancak karbonhidratlı besin seçiminde sadece Gİ değerinin dikkate alınmasının hatalı bazı yanları vardır. Düşük Gİ değerine sahip besinlerin enerji değerleri yüksek olabilmekte ve yüksek miktarlarda şeker veya yă̆ içerebilmektedirler (Mann ve ark., 2007).

Yüksek glisemik indeksli gıdalar, beyaz ekmek, patates ve kahvaltılık tahıllar; düşük glisemik indeksli gıdalar ise sebzeler, meyveler, sert kabuklu meyveler, kurubaklagiller ve tam tahıllar olarak bilinmektedir (Das ve ark., 2007). Gıdaların Gİ düzeyi içerdikleri nişasta, monosakkaritin yapısı, lif içeriği, olgunluk düzeyi, fitik asit ve fenolik asit gibi besin öğesi olmayan bileşikler, fiziksel yapıları, protein ve yağ içeriği, pişirme ve işleme teknikleri gibi pek çok faktörden etkilenmektedir (Jenkins ve ark., 2002). 
Bisküviler, hem kolay bulunabilir ve ucuz olması hem de pratik bir alternatif olmasından dolayı ara öğün ve atıştırmalık olarak günümüzde sıklıkla tüketilen gıda ürünlerinin başında gelmektedir. Bu sebeplerle günümüz beslenmesinde önemli bir yere sahip olan bisküvilerin çeşitliliği de gittikçe artmaktadır. Gİ ile ilgili yapılan araştırmalara her geçen gün bir yenisi eklenmekte, diyetin ya da besinlerin Gİ düzeylerinin sağlıkla ilişkisi tespit edilmeye çalışılmaktadır. Özellikle beden ağırlığı üzerindeki etkilerini netleştirebilmek amacıyla benzer birçok araştırma yapılmaktadır. Form ve light olarak bilinen bisküvilerin, ülkemizdeki tüketim oranlarının yüksekliği dikkate alınarak, sağlıklı beslenmedeki yerinin tespit edilmesi gerekliliğinden dolayı; glisemik indeks ve kan şekeri üzerine olan etkileri konusunda çalışmalara ihtiyaç vardır. Gıdaların Gİ' i in vivo olarak etik kurul onayını takiben yapılabilmektedir. Bu hem zaman hem de maliyet açısından özellikle ürün geliştirme aşamasında tercih edilmez. Günümüzde hızlı ve in vivo yöntemlerle korelasyonları sağlanmış in vitro Gİ analiz metotları mevcuttur. İn vitro olarak insan gastrointestinal sistemi simüle edilerek (ağız, mide, ince bağırsak) gıdaların GI' si yaklaşık 4-5 saat gibi kısa sürelerde belirlenebilmektedir.

Bu nedenle bu çalı̧̧mada; Gİ üzerine etki ettiği bilinen farklı lif, karbonhidrat ve nişasta kaynaklı içeriklerinden dolayı; kırmızı mercimek, spagetti ve pirinç unu ile yüksek lif içerikleriyle bilinen ve ara öğ̈̈nlerde atıştırmalık olarak sıklıkla tüketilen; yulaflı bisküvi, şekerli form bisküvi ve şekersiz form bisküvi örnekleri ile çalışılmıştır. Çalışmanın amacı; ülkemizde tüketilen çeşitli gıda ürünleri ile bisküvilerin Gİ' lerinin in vitro glisemik indeks metoduyla belirlenerek kıyaslanmasıdır.

\section{Materyal ve Metot}

\section{1. Örnekleme}

Bu çalışmaya; İstanbul'daki marketlerden satın alınan kırmızı mercimek, spagetti ve pirinç unu ile yulaflı bisküvi, şekersiz form bisküvi ve şekerli form bisküvi ürünleri dahil edilmiştir. Referans olarak, 2 ayrı ürün grubu için, farklı zamanlarda temin edilen 2 farklı beyaz ekmek numunesi kullanılmıştır ve bu numuneler referans ekmek 1 ve referans ekmek 2 olarak belirtilmiştir. Örnekler analiz için öğütülerek hazır hale getirilmiştir.

\subsection{Kimyasallar}

Hidroklorik asit $(\mathrm{HCl})$, sodyum hidroksit $(\mathrm{NaOH})$, sodyum asetat ( $\mathrm{NaAc})$, guar gum, GOPOD solüsyonu, pepsin (250 IU), pankreatin $(136 \mathrm{mg} / \mathrm{mL})$, amiloglikozidaz $(13.4 \mathrm{U} / \mathrm{mL})$ intervaz $(25.43 \mathrm{U} / \mathrm{mL})$.

\section{3. İn Vitro Glisemik İndeks Tayini}

Englyst ve arkadaşları (1992)' nın in vitro nişasta sindirilebilirliği metodu bazı değişikliklerle modifiye edilerek standartlaştırıldı. Sindirim için gerekli olan mide ve ince bağırsak solüsyonları, mide ve ince bağırsak enzimlerini içerecek şekilde 2 farklı türde hazırlandı (Englyst ve ark., 1992).

Mide Solüsyonu: >250 IU ünite enzim içeren pepsin enzimi ile 0,5 g guar gum $100 \mathrm{~mL}$ ' lik manyetik karıştırıı ile karıştırıldı. Üzerine bir miktar 0,1 N HCl ilave edildi ve manyetik karıştırıcı ile karıştırıldı. Daha sonra hacim 0,1 N HCl ile tamamlandı.

İnce Bağırsak Solüsyonu: Her bir örnek için $680 \mathrm{mg}$ pankreatin $50 \mathrm{~mL}$ ' lik falkon tüp içine aktarıldı ve üzerine $4 \mathrm{~mL}$ deiyonize su ilave edildi. Vorteks ile karıştııldıktan sonra 8000 rpm' de $10 \mathrm{dk}$ santrifüj edildi. Süpernatant kısım alınarak üzerine 67 IU amiloglikozidaz enzimi (AMG) ve $127.15 \mathrm{U}$ invertaz ilave edildi ve hacim $5 \mathrm{~mL}$ ' ye tamamland.

Homojen edilmiş $0,5 \mathrm{~g}$ sindirilebilir karbonhidrat içeren örnek $250 \mathrm{~mL}$ ' lik erlen içine tartıldı. Üzerine $5 \mathrm{~mL}$ deiyonize su ve hazırlanmış enzim solüsyonu 1' den $10 \mathrm{~mL}$ ilave edildi ve $37^{\circ} \mathrm{C}$ 'de çalkalamalı su banyosunda $30 \mathrm{dk}$ inkübe edildi. Daha sonra $5,0 \mathrm{~mL}$ $0,5 \mathrm{M}$ sodyum asetat ilave edildi ve $\mathrm{pH} 5.2^{\prime}$ ye ayarlandi. Enzim solüsyonu 2' den $5 \mathrm{~mL}$ ilave edildi ve hacim deiyonize su ile $100 \mathrm{~mL}$ ye tamamland. Çalkalamalı su banyosunda $37^{\circ} \mathrm{C}^{\prime}$ de inkübe edildi. $30,60,90,120,150$ ve 180 . dakikalarda numunelerden, $10 \mathrm{~mL}$ ' lik cam tüp içine $0,5 \mathrm{~mL}$ alındı. Enzim denatürasyonu için $100^{\circ} \mathrm{C}^{\prime}$ deki su banyosunda $5 \mathrm{dk}$ bekletildi. Örnek deiyonize su ile $15 \mathrm{~mL}$ ' lik plastik falkon tüp içine alındı ve hacmi $5 \mathrm{~mL}$ ' ye tamamlandı. $8000 \mathrm{rpm}$ ' de $5 \mathrm{dk}$ santrifüj edildi. Örnekten $0,1 \mathrm{~mL} 10 \mathrm{ml}$ ' lik cam tüp içine alındı ve üzerine $3 \mathrm{~mL}$ GOPOD enzim çözeltisinden ilave edildi. $50^{\circ} \mathrm{C}^{\prime}$ de su banyosunda $20 \mathrm{dk}$ bekletildi ve daha sonra spektrofotometrede $510 \mathrm{~nm}$ ' de absorbansları ölçüldü.

HI' ler 0-180' dk arasında test numunesinin hidroliz eğrisisin altında kalan alanın (AUC) referans numune (beyaz ekmek) eğrisinin altında kalan alana oranlanması ile elde edilir. Numunelerin hidroliz indeksi, numuneden oluşan hidroliz eğrisi altındaki alanın ( 0 ila 180 dakika) beyaz bir ekmek alanıyla (referans numune, beyaz ekmek) karşılaştırılmasıyla hesaplandı. Daha sonra Goni ve ark. (1996) tarafindan tanımlanan denklem kullanılarak numunelerin Gí’ leri hesaplandı (Goni ve ark., 1996).

$$
\mathrm{GI}=39.71+0.549 . \mathrm{H} \dot{ } \text {. }
$$

\section{4. İstatistiksel Analizler}

İstatistiksel analizler, Tukey (ANOVA) testi kullanılarak yapıldı. Tüm önemli farkl1lıklar, anlamlılık $\mathrm{p}<0,05$ düzeyinde rapor edilmiştir.

\section{Araştırma Sonuçları ve Tartışma}


Tablo 1'de kırmızı mercimek, spagetti, pirinç unu ve beyaz ekmeğin 0 ile 180 dakika arasındaki hidroliz oranları verilmiştir. Gıda ürünlerinin glisemik indeks değerlerini hesaplamak için referans olarak beyaz ekmek kullanılmıştır. Genellikle referans gıda olarak glukoz kullanılır ve glukozun Gİ değeri 100 olarak tanımlanır. Örneğin 50 g sindirilebilir karbonhidratı sağlayacak miktarda patates tüketilirse, alınan 50 g glukoz; referans ile kıyaslandığında kan glukozu yanıtının \%80' ine neden olmaktadır. Bu durumda patatesin Gi değeri 80 olmaktadır (Monro ve Mishra, 2009; Jamurtas ve ark., 2013).

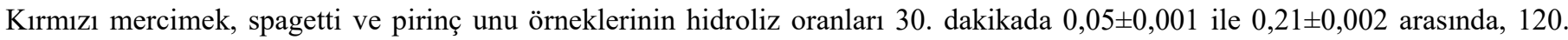

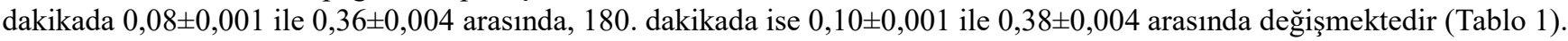

Tablo 1. Bazl gidaların 0 ve 180 dakika arasında hidroliz oranlarl

\begin{tabular}{lcccccc}
\hline \multicolumn{1}{c}{ Örnekler } & $\mathbf{0 ~ d k}$ & $\mathbf{3 0} \mathbf{d k}$ & $\mathbf{6 0 ~ d k}$ & $\mathbf{9 0 ~ d k}$ & $\mathbf{1 2 0} \mathbf{d k}$ & $\mathbf{1 8 0 ~ d k}$ \\
\hline Kırmızı mercimek & 0 & $0,05 \pm 0,001$ & $0,06 \pm 0,001$ & $0,07 \pm 0,001$ & $0,08 \pm 0,001$ & $0,10 \pm 0,001$ \\
Spagetti & 0 & $0,17 \pm 0,002$ & $0,24 \pm 0,003$ & $0,30 \pm 0,003$ & $0,30 \pm 0,003$ & $0,32 \pm 0,004$ \\
Pirinç unu & 0 & $0,21 \pm 0,002$ & $0,27 \pm 0,003$ & $0,33 \pm 0,004$ & $0,36 \pm 0,004$ & $0,38 \pm 0,004$ \\
Referans ekmek 1 & 0 & $0,31 \pm 0,004$ & $0,42 \pm 0,005$ & $0,53 \pm 0,006$ & $0,59 \pm 0,007$ & $0,65 \pm 0,007$ \\
\hline
\end{tabular}

Tablo 1' deki gıdalar kıyaslandığında en hızlı hidroliz pirinç ununda görülürken (180. dakikada 0,38 $\pm 0,004)$, en yavaş hidroliz

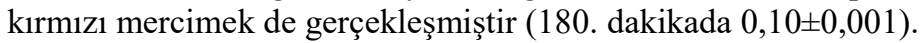

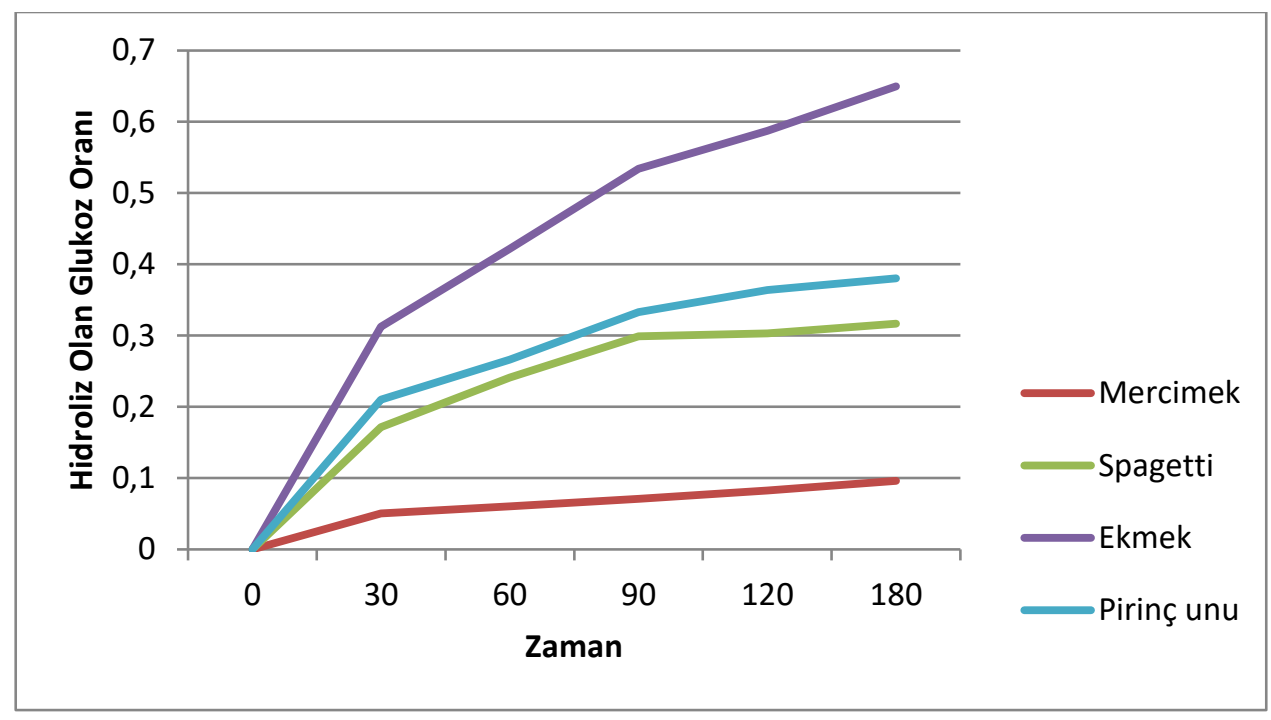

Şekil 1. Bazı gıdaların beyaz ekmeğe göre hidroliz grafikleri

Şekil 1' de gıda örneklerinin beyaz ekmeğe göre hidroliz grafikleri gösterilmektedir. Karbonhidrat içeren öğünlere diyet lifinin eklenmesi glisemik yanıtı azaltmaktadır. Çözünebilir lif, kıvamlı çözelti oluşturarak gastrik boşalmayı yavaşlatmasıyla ince bağırsak lümeninde difüzyonu azaltıp sonuç olarak sindirim hızını ve bağırsaktan glukoz emilimini azaltmaktadır (Nayak ve ark., 2014).

Bisküvi örneklerinin hidroliz oranları 30. dakikada $0,34 \pm 0,015$ ile $0,46 \pm 0,021$ arasında, 120 . dakikada $0,58 \pm 0,026$ ile $0,77 \pm 0,035$

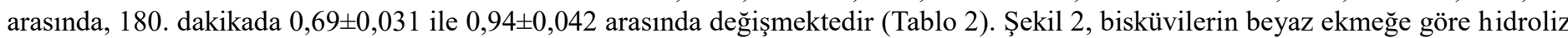
grafiklerini göstermektedir.

Tablo 2. Bisküvilerin 0 ve 180 dakika arasında hidroliz oranları

\begin{tabular}{lccccccc}
\hline \multicolumn{1}{c}{ Örnekler } & $\mathbf{0 ~ d k}$ & $\mathbf{3 0} \mathbf{d k}$ & $\mathbf{6 0} \mathbf{d k}$ & $\mathbf{9 0} \mathbf{d k}$ & $\mathbf{1 2 0} \mathbf{d k}$ & $\mathbf{1 5 0} \mathbf{d k}$ & $\mathbf{1 8 0} \mathbf{d k}$ \\
\hline Yulaflı bisküvi & 0 & $0,37 \pm 0,017$ & $0,49 \pm 0,022$ & $0,57 \pm 0,025$ & $0,59 \pm 0,027$ & $0,62 \pm 0,028$ & $0,71 \pm 0,032$ \\
$\begin{array}{l}\text { Form şekersiz } \\
\text { bisküvi }\end{array}$ & 0 & $0,46 \pm 0,021$ & $0,58 \pm 0,026$ & $0,68 \pm 0,031$ & $0,77 \pm 0,035$ & $0,87 \pm 0,039$ & $0,94 \pm 0,042$ \\
$\begin{array}{l}\text { Form şekerli } \\
\text { bisküvi }\end{array}$ & 0 & $0,34 \pm 0,015$ & $0,47 \pm 0,021$ & $0,53 \pm 0,024$ & $0,58 \pm 0,026$ & $0,58 \pm 0,026$ & $0,69 \pm 0,031$ \\
Referans ekmek 2 & 0 & $0,42 \pm 0,019$ & $0,55 \pm 0,025$ & $0,61 \pm 0,028$ & $0,73 \pm 0,033$ & $0,77 \pm 0,035$ & $0,82 \pm 0,037$ \\
\hline
\end{tabular}

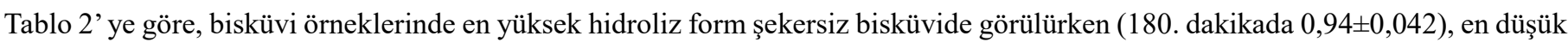

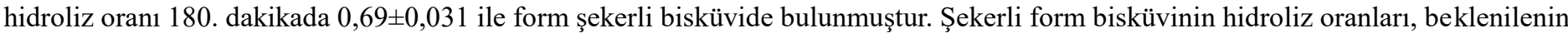
tam tersine şekersiz form bisküviden anlamlı bir farklılıkla düşük bulunmuştur. Şeker içeren form bisküvinin hidroliz oranlarının şekersiz form bisküviye göre yüksek olması beklenirken, anlamlı farklılıkla düşük çıkmasının sebebi yüksek lif içermesinden 
kaynaklanabilmektedir. Şeker içeren form bisküvinin içeriğindeki; yulaf, çavdar, beta-glukan gibi bileşenler glukozun hızlı sindirimine engel olmaktadır. Bilindiği gibi, yüksek lif içeren bileşenler glukozun sindirimini engelleyerek yavaşlatmaktadır (Memiş ve Şanlıer, 2009).

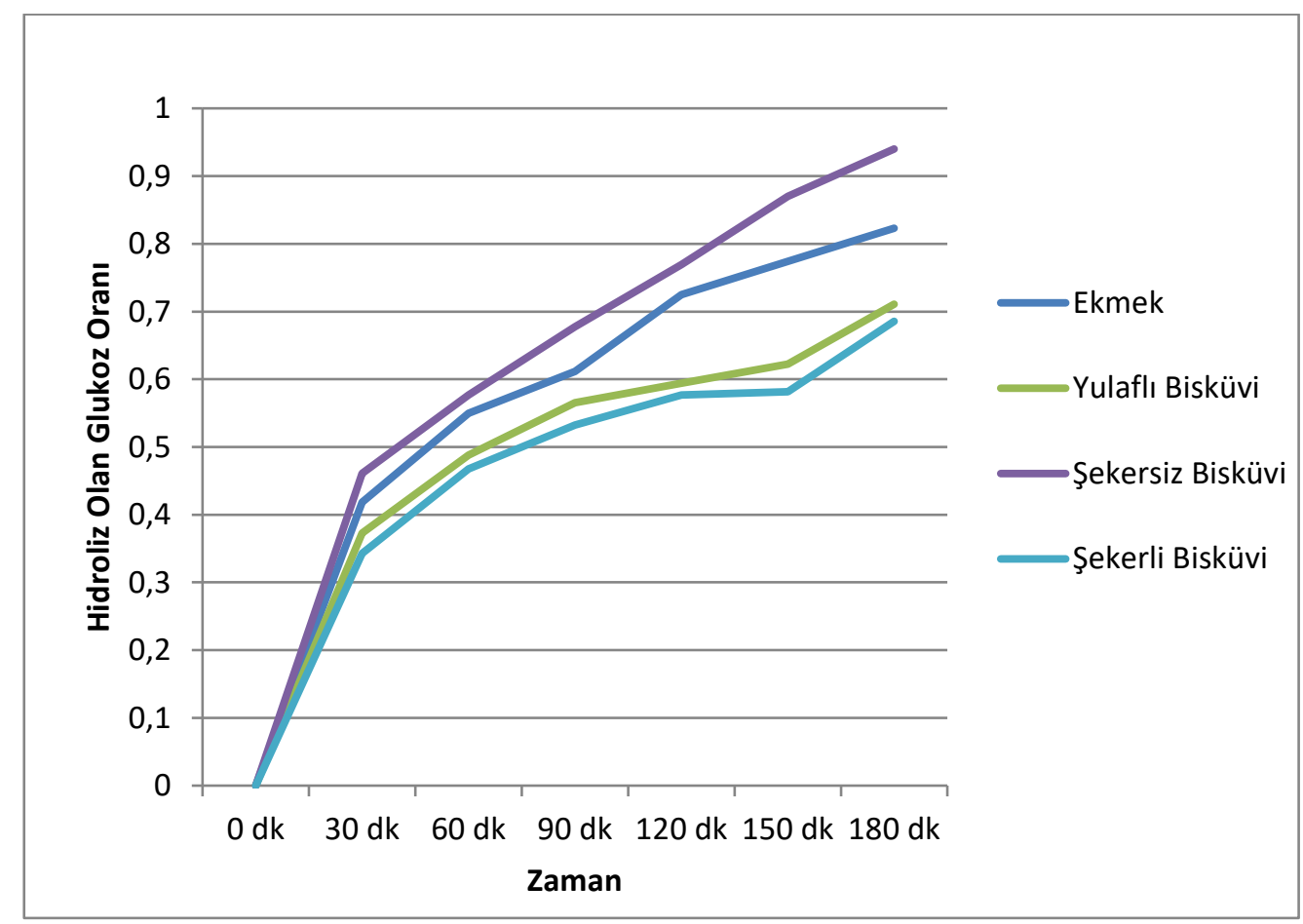

Şekil 2. Bisküvilerin beyaz ekmeğe göre hidroliz grafikleri

Kırmızı mercimek, spagetti ve pirinç unu ile bisküvi örneklerine ait hidroliz indeks (Hi) ve glisemik indeks (Gí) değerleri Tablo 3' de verilmiştir. Gıda örneklerinin Hİ' leri 14,4 ile 62,3 arasında, Gİ' leri ise 33,3 ile 51,7 arasında değişmektedir. Referans alınan beyaz ekmek $(66,4)$ ile kıyaslandığında Gİ’ ler üç örnekte de düşük bulunmuştur.

2 ayrı örneklem grubunda 2 farklı beyaz ekmek kullanılmıştır. Beyaz ekmeklerin glisemik indeksleri, denklemde beyaz ekmeğin hidroliz indeksi 100 olarak kabul edildiğinde, birinci grup gıda örneklerinde 66,4 olarak hesaplanırken, ikinci grup bisküvi örneklerinde ise 66,2 olarak hesaplanmıştır. Sükrozun glisemik indeks değeri (beyaz ekmek referans alındığında) 65 'in altında iken glukozun Gi değeri 97, früktoz ve laktozun sırasıyla Gİ değeri 23 ve 46'dır (Pi-Sunyer, 2002). Glukoz içeriği yüksek olan besinlerin glisemik indeks değerleri früktoz içeren besinlere göre yüksektir (Memiş ve Şanlıer, 2009).

Tüm örnekler arasında en düşük Gİ değeri 33,3 ile kırmızı mercimekte bulunmuştur. Baklagillerin amiloz oranı tahıl ürünlerine göre daha fazla olduğundan Gİ değeri düşüktür, sindirim enzimleri tarafindan sindirilemeyen veya sindirilmeye direnç gösteren nişasta fraksiyonu "dirençli nişasta" baklagillerde tahıllara göre daha fazla bulunmaktadır (Nayak ve ark., 2014).

Jenkins ve ark. (1988), bu çalışmanın sonuçlarıyla uyumlu olarak, çalışmalarında kırmızı mercimek Gí değerini $37 \pm 6$ tespit etmişlerdir (Jenkins ve ark., 1988). Bir gıdanın lif içeriği glisemik indeksini etkilemektedir. Bulunduğu sistemin viskositesini arttıran $\beta$-glukanlar, pektinler ve gamlar gibi suda çözünen lif türleri besinin mideden ince barsağa geçişini yavaşlatarak ve enzimlerin substrata ulaşmasını engelleyerek Gİ değerini düşürmektedir (Memiş ve Şanlıer, 2009). Yapılan bir çalıșmada, hiç lif içermeyen 6 farklı nişastalı besin (Gİ değerleri 52-72 arasında) ve $250 \mathrm{~mL}$ suda çözünmüş $2.5 \mathrm{~g}$ veya $5 \mathrm{~g}$ granüller PGX'i (viskoz lif suplemanı) tükettirilmiştir. 2.5g PGX tüketildiğinde besinlerin Gİ değeri \%19 azalırken, $5 \mathrm{~g}$ tüketildiğinde \%30 düştüğü görülmüştür (Brand-Miller ve ark., 2012).

$\mathrm{Bu}$ çalışmada, kırmızı mercimek ve makarnanın Gİ değerleri, pirinç unu Gİ değerinden $(51,7)$ düşük bulunmuştur. Besinin fiziksel yapısı da Gİ değerini etkileyen bir parametredir. Yoğun yapılı besinler örneğin findık, makarna, baklagiller ve viskoz besinler daha yavaş sindirilmektedir. Böylece, kan dolaşımına glukoz salınımı yavaşlamakta ve bu durum düşük Gİ ile sonuçlanmaktadır. Viskoz olmayan sıvılar veya ekmek gibi besinlerde amilaz karbonhidratları yıkmakta ve sonuç olarak glukoz hızlıca kan dolaşımına katılmaktadır (Jones, 2012).

Bisküvilerin Hİ' leri 81,5 ile 109,6 arasında, Gİ' leri ise 59,1 ile 69,9 arasında değişmektedir. Referans alınan beyaz ekmek $(66,2)$ ile bisküvilerin Gİ' leri kıyaslandığında, Gİ sadece form şekersiz bisküvide yüksek bulunmuştur. Yulaflı bisküvi ve form şekerli bisküvinin GI' leri düşük bulunmuştur. Şekersiz form bisküvinin beklenenin tersine yüksek Gİ' li bulunması, çok daha düşük miktarda lif içerdiğini göstermektedir. Şekerli form ve şekersiz form bisküvilerin paketlerindeki etiket bilgileri incelendiğinde lif miktarlarının yaklaşık 2 katı kadar farklı olduğu görülmüştür. Bu çalışmanın sonuçları ile uyumlu olarak, yüksek Gİ' li bulunan şekersiz form bisküvinin lif miktarı şekerli form bisküvinin yaklaşık yarısı kadardır. Bu da, gıda ürünlerinin içerğindeki lifin kaynak ve miktarının Gi değeri üzerine olan olumlu etkisini açıklamaktadır ve çalışmanın sonuçlarını desteklemektedir. Normal günlük diyette alınması gereken lif oranı 25-38 g/gün olarak önerilmektedir (TÜBER, 2016). 
Foster-Powell ve ark. (2002) çalışmasında yulaflı ve form özellikteki bisküvilerin Gİ değerleri $57 \pm 3$ ile $70 \pm 3$ aralığında olduğu bildirilmiştir. Foster-Powell ve ark. (2002)' nın çalışması, bu çalışmada 59,1-69,9 aralığında bulunan Gí sonuçlarını desteklemektedir. Ayrıca, yulaflı bisküvi' nin $57 \pm 4$ olarak bildirilen Gİ değeri de bu çalışmadaki yulaflı bisküvi Gİ $(60,8)$ sonucuyla oldukça uyumludur (Foster-Powell ve ark., 2002).

Yulaflı bisküvin Gİ’ inin şekersiz form bisküviden düşük bulunması da, yüksek lifin Gİ üzerindeki olumlu etkisini ortaya koymaktadır. Yulaf, postprandiyal kan glukozunu ve insülin yanıtlarını azaltmada rol oynayan biyo aktif bir madde olan $\beta$-glukan içeriğiyle bu çalışmayı desteklemektedir (Koh-Banerjee ve ark., 2004). Malezya' da diyabetli hastalar üzerinde yapılan küçük bir çalışmada, yulaf tüketimi ile bozulmuş glukoz toleransı (IGT) arasında bir ilişki bulunmuş, ancak bu ilişki mısır gevreği ile yapılan çalışmalarda bulunamamıştır (Munirah ve ark., 2012).

Selüloz yüksek çözünmez lif içeriği sayesinde düşük glisemik indekse sahiptir (Foster-Powell ve ark., 2002) ve genellikle kepekli ürünler ve kahverengi pirinç de dahil olmak üzere ev tipi gıda ürünlerinde en çok bulunan polisakkarit olarak kabul edilir. Selüloz çözünmez olduğu için bu gıdalar diyet lif içeriğinin arttırllıp artırılmadığına bakılmaksızın aynı glisemik indeks değerine sahiptir (Jenkins ve ark., 2002).

Bu çalışmada, yulaf ve kepek içeriği yüksek olduğu bilinen bisküvi örneklerinin Gİ değerleri nispeten yüksek bulundu. Pişirme koşulları, hücre duvarını, granülün yapısını ve jelatinizasyonu bozarak glisemik indeks değerini arttırmaktadır. Fırınlanmış pul pul olmuş bir besinin glisemik yanıtının, çiğ buğday gevreğinin glisemik yanıtına benzediği bildirilmiştir (Nayak ve ark., 2014).

Tablo 3. Bazı gıdaların ve bisküvilerin hidroliz indeks ve glisemik indeks değerleri

\begin{tabular}{lcclcc}
\hline Gıda örnekleri & Hí & Gí & Bisküvi örnekleri & Hi & Gí \\
\hline Kırmızı mercimek & 14,4 & 33,3 & Yulaflı bisküvi & 85,9 & 60,8 \\
Spagetti & 53,2 & 48,3 & Form şekersiz bisküvi & 109,6 & 69,9 \\
Pirinç unu & 62,3 & 51,7 & Form şekerli bisküvi & 81,5 & 59,1 \\
Referans ekmek 1 & 100 & 66,4 & Referans ekmek 2 & 100 & 66,2 \\
\hline
\end{tabular}

Hu ve ark. (2004), pirincin diğer nişastalı gıdalara kıyasla nispeten yüksek bir glisemik cevaba sahip olduğu bildirmektedir (Hu ve ark., 2004). Bu çalışmada pirinç unu 51,7 Gİ değeri ile kendi grubunda en yüksek glisemik indeks değerinde bulunmuştur.

Bir besinin içerdiği karbonhidratın ve besinin emilim hızını etkileyen birçok etmen bulunmaktadır ve bunlar besinin Gí değerini de etkilemektedir. Bu etmenler, besinin sindirilme oranı, geçiş zamanı, yapısı, hazırlanma şekli, olgunluğu, protein ile yağ içeriği, lifin miktarı ve türü, yapısındaki nişastanın şekli (amiloz veya amilopektin oranının baskın olması), monosakkarit bileşenleri, $\alpha$-amilaz inhibitörleri gibi besin ögesi olmayan bileşikleri içermektedir (Wong ve ark., 2010). Brennan ve Brennan (2009), işlenmiş gıdalarda yavaş sindirilebilen nişasta (YSN) miktarını artırma ile glisemik indeks oranını azaltmanın mümkün olduğunu göstermiştir (Brennan ve Brennan, 2009).

Diyabet, dünya çapında artmaya devam eden küresel bir sağlık sorunudur. Refah düzeyinin artışına bağlı olarak bireylerin beslenme alışkanlıklarının farklılaştığı ve günlük enerji ihtiyacında yer alan karbonhidratların yapısının değiştĭgi, basit karbonhidratlara göre kompleks karbonhidrat tüketim oranının arttığı belirtilmektedir. Günümüzde diyabete bağlı hastalıklar nedeniyle ölüm oranlarının sürekli arttığı Amerika Birleşik Devletleri'nde TIP 2 DM prevalansındaki artışının en büyük nedenlerinden biri olarak rafine edilmiş karbonhidratlı gıda tüketiminin artması ve buna paralel olarak alınması gereken günlük lif ihtiyacının yeterince karşılanmadığı gösterilmektedir (Gross ve ark., 2004). "Amerikan Diabetes Association" (ADA) verilerine göre 2013 y1lı itibariyle ülkede toplam 26 milyon diyabet hastası (toplam nüfusun \%8,3'ü) ve 79 milyon prediyabetik birey bulunmaktadır (ADA, 2017). Atıştırmalık bisküvilerde olduğu gibi, yüksek Gİ'e sahip besinlerin tüketiminin, düşük GI'e sahip besinlere kıyasla artması diyabet oranındaki artışı açıklamaktadır (Wong ve ark., 2010). Tip 2 diyabet (TIP 2 DM) hastalarında diyet programı ve kilo kontrolü eğitiminin diyabetin tedavisinde önemli bir yeri vardır. Diyabetin tedavisinde kullanılan diyette alınan toplam kalorinin \%50-60'ı karbonhidratlardan, \%1520 'si proteinlerden ve $\% 30$ 'u ise yağlardan oluşmalıdır (Kumar ve ark., 2018). Yulaf veya yulaf bazlı tahılların hipokalorik bir diyette yararını destekleyen kanitlar bulunmaktadır (Chang ve ark., 2013). Brennan ve Brennan (2009), yüksek Gİ' li gıdalar içeren diyetleri; kilo artışı, insülin eksikliği, bozulmuş kan glukozu kontrolü ve artan obezite seviyeleri ile ilişkilendirmiştir (Brennan ve Brennan, 2009).

\section{Sonuç}

$\mathrm{Bu}$ çalışmada, günlük beslenmemizde sıklıkla kullanılan kırmızı mercimek, spagetti ve pirinç unu gibi bazı gıda ürünleri ile form, diyet ve light olmasıyla bilinen bazı bisküvilerin glisemik indeks değerleri in vitro yöntem ile belirlenmiş̧tir. Sonuç olarak, birinci örneklem grubunda yer alan gıdaların glisemik indeksleri beyaz ekmekten daha düşük bulunurken, ikinci örneklem grubunda yer alan bisküvilerde ise bir tanesi beyaz ekmekten daha yüksek (form şekersiz bisküvi), diğer ikisi düşük bulunmuştur. Yulaflı bisküvinin düşük GI' li olması beklenen bir sonuç iken, form şekerli bisküvi örneğinin GI' inin düşük bulunmasının, içeriğindeki yüksek lif miktarından kaynaklandığı düşünülmektedir. Benzer şekilde, şekersiz form bisküvinin beklenenin tersine yüksek Gí’ li bulunması, çok daha düşük miktarda lif içerdiğini göstermektedir.

$\mathrm{Bu}$ çalışmanın literatürü destekleyen sonuçları, diyet lifinin gıda ürünlerinin glisemik indeksine olan olumlu etkisini vurgulamaktadır. Gıda ürünü şekerli dahi olsa, yüksek lif içeriği glukozun hidrolizini engelleyerek yavaşlatmıştır. Her ne kadar form bisküvi ürünleri halk arasında sağlıklı atıştırmalıklara alternatif olarak görülse de, bu çalışmanın sonuçları göstermektedir ki, form bisküvilerin glisemik indeksleri nispeten yüksektir. 
Gıdaların Gİ' i in vivo olarak etik kurul onayını takiben yapılabilmektedir. Bu hem zaman hem de maliyet açısından özellikle ürün geliştirme aşamasında tercih edilmez. İn vitro olarak, insan gastrointestinal sistemi simüle edilerek (ağız, mide, ince bağırsak) gıdaların GI' inin yaklaşık 4-5 saat gibi kısa sürelerde belirlendiği bu yöntem, bir avantaj olarak karşımıza çıkmaktadır. Çalışmanın literatürü oldukça yakından destekleyen sonuçları, in vitro yöntemin glisemik indeks tayinindeki güvenilirliğini ortaya koymaktadır.

Ülkemizde Gİ verileri sadece yapılan çalışmalar ve raporlarda bildirilmektedir. Tüketicinin bu konuda bilinçlendirilmesi sağlanıp, bu verilere ulaşması kolaylaştııılmalıdır. Tüketici tarafından gıdaların ve gıda ürünlerinin Gİ' lerinin bilinmesi faydalı ve kesin bir çözüm olacağından, Türk Gıda Kodeksi’ nde etiket bilgilerinde Gİ verilerinin yer alması önerilmektedir.

Yüksek glisemik indeksli bisküvilerin tüketimi, uzun veya kısa vadede insülin eksikliğine, kan şekeri seviyelerinin artmasına ve şişmanlık seviyelerinin artmasına neden olabilir. Kan şekerine etkisinden dolayı beslenmede düşük glisemik indeksli gıdalar ve gıda ürünleri tercih edilmelidir Yüksek glisemik indekse sahip ürünlerin glisemik indeksini azaltmaya yönelik çalışmalar arttırılarak yulafla formüle edilmesi önerilmektedir.

\section{Kaynakça}

ADA (2017). American Diabetes Association (2017). 2. Classification and diagnosis of diabetes. Diabetes care, 40 (Supplement 1), S11S24.

Bell, S.J. \& B. Sears, (2003). Low-Glycemic-Load Diets: Impact on Obesity and Chronic Diseases, Critical Reviews in Food Science and Nutrition, 43:4, 357-377, DOI: 10.1080/10408690390826554.

Brand-Miller, J. C., Atkinson, F. S., Gahler, R. J., Kacinik, V., Lyon, M. R., \& Wood, S. (2012). Effects of added PGX®, a novel functional fibre, on the glycaemic index of starchy foods. British Journal of Nutrition, 108(2), 245-248.

Brennan, C. S. (2005). Dietary Fibre, Glycaemic response, and Diabetes. Molecular Nutrition and Food Research 49, 560-570.

Brennan, C. S., \& Brennan, M. A. (2009). Glycemic response reduction in processed food products. In Modern Biopolymer Science (pp. 511-518). Academic Press.

Chang, H. C., Huang, C. N., Yeh, D. M., Wang, S. J., Peng, C. H., \& Wang, C. J. (2013). Oat prevents obesity and abdominal fat distribution, and improves liver function in humans. Plant Foods for Human Nutrition, 68(1), 18-2.

Chiu, C. J., Liu, S., Willett, W. C., Wolever, T. M., Brand-Miller, J. C., Barclay, A. W., \& Taylor, A. (2011). Informing food choices and health outcomes by use of the dietary glycemic index. Nutrition Reviews, 69(4), 231-242.

Das, S. K., Gilhooly, C. H., Golden, J. K., Pittas, A. G., Fuss, P. J., Cheatham et al., (2007). Long-term effects of 2 energy-restricted diets differing in glycemic load on dietary adherence, body composition, and metabolism in CALERIE: a 1-y randomized controlled trial. The American Journal of Clinical Nutrition, 85(4), 1023-1030.

Englyst, H. N., Kingman, S. M., \& Cummings, J. H. (1992). Classification and measurement of nutritionally important starch fractions. European Journal of Clinical Nutrition, 46, S33-50.

EFSA (2012). Panel on Dietetic Products, Nutrition and Allergies (NDA). Scientific Opinion on the substantiation of a health claim related to cocoa flavanols and maintenance of normal endothelium-dependent vasodilation pursuant to Article 13 (5) of Regulation (EC) No 1924/2006. EFSA Journal, 10(7), 2809.

(FAO/WHO) (1998), Food and Agricultural Organization/ World Health Organization. Carbohydrates in Human Nutrition: Report of a Joint FAO/WHO Expert Consultation, April 14-18, 1997; Food and nutrition paper. Rome: FAO. 140 pp.

Foster-Powell, K., Holt, S. H., \& Brand-Miller, J. C. (2002). International table of glycemic index and glycemic load values: 2002. The American Journal of Clinical Nutrition, 76(1), 5-56.

Goñi, I., Garcia-Diz, L., Mañas, E., \& Saura-Calixto, F. (1996). Analysis of resistant starch: a method for foods and food products. Food Chemistry, 56(4), 445-449.

Gross, L. S., Li, L., Ford, E. S., \& Liu, S. (2004). Increased consumption of refined carbohydrates and the epidemic of type 2 diabetes in the United States: an ecologic assessment. The American Journal of Clinical Nutrition, 79(5), 774-779.

Hu, P., Zhao, H., Duan, Z., Linlin, Z., \& Wu, D. (2004). Starch digestibility and the estimated glycemic score of different types of rice differing in amylose contents. Journal of Cereal Science, 40(3), 231-237.

Jamurtas, A.Z., Deli, C.K., Georgakouli, K., \& Fatouros, I.G. (2013). Chapter 2- Glycemic Index, Food Exchange Values and Exercise Performance. D. Bagchi, S. Nair \& C. K. Sen (Ed.). Nutrition and Enhanced Sports Performance (s. 9-27). San Diego: Academic Press.

Jenkins, D. J., Wolever, T. M., \& Jenkins, A. L. (1988). Starchy foods and glycemic index. Diabetes Care, 11(2), 149-159.

Jenkins, D. J., Kendall, C. W., Augustin, L. S., Franceschi, S., Hamidi, M., Marchie, A., Jenkins A.L., \& Axelsen, M. (2002). Glycemic index: overview of implications in health and disease. The American Journal of Clinical Nutrition, 76(1), 266S-273S.

Jones, J. M. (2012). Glycemic index: The state of the science, part 1-The measure and its variability. Nutrition Today, 47(5), 207-213.

Koh-Banerjee, P., Franz, M., Sampson, L., Liu, S., Jacobs Jr, D. R., Spiegelman, D., \& Rimm, E. (2004). Changes in whole-grain, bran, and cereal fiber consumption in relation to 8-y weight gain among men. The American Journal of Clinical Nutrition, 80(5), 12371245.

Kumar, A., Mittal, R., \& Kaur, A. (2018). Insulin Resistance in Diabetes: Present and Future Prospective of Treatment. Current Psychopharmacology, 7(2), 94-106.

Mann, J., Cummings, J., Englyst, H., Key, T., Liu, S., Riccardi, G. et al. (2007) FAO/WHO scientific update on carbohydrates in human nutrition: conclusions. European Journal of Clinical Nutrition, 61, S132-S137.

Memiş, E., \& Şanlıer, N. (2009). Glisemik indeks ve sağlık ilişkisi. Gazi Üniversitesi Endüstriyel Sanatlar Eğitim Fakültesi Dergisi, 24, $17-27$. 
Monro, J., \& Mishra, S. (2009). Chapter 13 - Nutritional Value of Potatoes: Digestibility, Glycemic Index, and Glycemic Impact. J. Singh \& L. Kaur (Ed.). Advances in Potato Chemistry and Technology (s. 371-394). San Diego: Academic Press.

Munirah, M. N., Shafurah, A. S., Norazmir, M. N., Adilin, M. A. H., \& Ajau, D. (2012). Roles of whole grains-based products in maintaining treatment targets among type 2 diabetes mellitus patients. Asian Journal of Clinical Nutrition, 4(2), 67-76.

Nayak, B., Berrios, J. D. J., \& Tang, J. (2014). Impact of food processing on the glycemic index (GI) of potato products. Food Research International, 56, 35-46.

Peyser, T. A., Balo, A. K., Buckingham, B. A., Hirsch, I. B., \& Garcia, A. (2018). Glycemic variability percentage: a novel method for assessing glycemic variability from continuous glucose monitor data. Diabetes Technology \& Therapeutics, 20(1), 6-16.

Pi-Sunyer, F. X. (2002). Glycemic index and disease. The American Journal of Clinical Nutrition, 76(1), 290S-298S.

TÜBER. (2016). Türkiye Beslenme Rehberi 2015 Sağlık Bakanlığı Yayın No: 1031.

TÜRKOMP (2013) Ulusal Gida Kompozisyon Veri Tabanı. (2013). http://www.turkomp.gov.tr. Erişim tarihi: 1 Ağustos, 2019.

Wild, S., Roglic, G., Green, A., Sicree, R., \& King, H. (2004). Global prevalence of diabetes: estimates for the year 2000 and projections for 2030. Diabetes Care, 27(5), 1047-1053.

Wong, J.M.W., Josse, A.R., Augustin, L., Saxena, N., Chiavaroli, L., Kendall, C.W.C. et al. (2010). Chapter 17 - Implications of the Glycemic Index in Obesity. L. Dubé, A. Bechara, A. Dagher, A. Drewnowski, J. Lebel, P. James \& R. Y. Yada (Ed.). Obesity Prevention (s. 219-230). San Diego: Academic Press. 